\title{
Brand Tribe Paradoxes: An Overview with Empirical Evidence from Pakistan
}

\author{
Mohammad Ali ${ }^{1} \&$ Sher Akbar ${ }^{2}$ \\ ${ }^{1}$ Management Sciences Department, COMSATS University Islamabad, Pakistan \\ Correspondence: Mohammad Ali, Management Sciences COMSATS University Islamabad, Pakistan. E-mail: \\ m_ali@cuiatd.edu.pk
}

Received: March 8, 2020

Accepted: March 16, 2020

Online Published: March 30, 2020

doi:10.5539/ass.v16n4p49

URL: https://doi.org/10.5539/ass.v16n4p49

\begin{abstract}
Due to the increased importance of marketing, concepts of marketing are continually evolving in the digital era. Creation of consumer tribe for brand promotion and consumption is one of the widely discussed concepts in marketing. As per literature, a tribe is a heterogeneous group of people presenting common interest and preferences for a brand. The links between consumer tribes are weak. Marketers through a marketing campaign, try to strengthen this relationship. Tribalism and tribe activity in favor of brand can be done through two approaches. The first approach is the postmodern approach which encourages users to get a higher status (Platinum, Gold or Silver) in the community via spending more. In contrasts, the second approach of a marketer is based on stimulating and activating a group of users through an opportunity or threat, i.e. limited time offers. However, the creation of tribes and the implementation of these campaigns are not well explained in the literature. Marketers always make haphazard efforts between these approaches while making campaigns. Gap has motivated the researchers to explore and investigate these paradigms of brand tribalism in detail. The current research paper explains and compares the two tribalism approaches. Through the collection of data from automobiles users across Pakistan, the authors have validated and compared both frameworks i.e. anthropological tribal approach and postmodern tribal approach. It has been concluded that the anthropologist approach is better in the context of car market of Pakistan. The researchers recommend the practitioners to follow one approach while creating brand tribes in relationship marketing. The article in detail has guidelines for the markers in the automobile industry. The paper also shares future research areas in brand tribalism for academicians.
\end{abstract}

Keywords: brand tribe, postmodernism, anthropology, Pakistan, empirical study

\section{Introduction}

Humans are social species. Since inception, humans lived in tribes to fulfill their basic need of safety, security and emotional need of belonging (Arvidsson, 2005; Donnelly et al., 2009; Escalas \& Bettman, 2005; Kotler \& Armstrong, 2010; Ramaiyah \& Ahmad et al., 2010). As the marketing core focus is understanding the human needs and desires, therefore, the marketers have also focused on the fundamental desire of human belonging from a tribe (Ataman et al., 2008; Szõcs, 2014). This belonging sense has further evolved in the digital era where the companies have used users data to rank and categorize users and give the titles such as platinum and gold customers (Bauer et al., 2008; Farooq et al., 2016; Raza et al., 2018). However, this detailed investigation and knowledge of humans led to further complexities in relationship management and brand development. There are several perspective and dimensions in relationship management (Chapman, 2020; Reich \& Maglio, 2020; Zeithaml et al., 2020). Applying the perfect approach in right context yields better results. Therefore, the current study has investigated the dimension and tribalism thoroughly and validates the concepts from empirical data. The research paper holistically defines tribes, explains the two types of tribal creation approaches the postmodern tribe and the anthropological perspective of the tribe.

Furthermore, the paper collected the data from car users of different brands using different models to identify the best tribe approach. The paper validates both models to identify the best approach in the context of Pakistan. The perspective of postmodernism focuses on individualism based tribe's creation where users are encouraged to get a prominent position in the tribe by spending more and having a better perceptive (de Kock et al., 2011; Tsai, 2005; Veloutsou, 2015) whereas, the anthropological perspective stimulates the purchase behavior of users based 
on threat and opportunity (Kim et al., 2010; Reimer \& Walter, 2013; Sharma, 2013).

This paper has two-fold contributions for practitioners; it can act as a guiding source for strategy development. For the academics, it provides extensive literature on tribalism and a way forward for future research. Brand tribalism is a well-recognized concept in marketing which got the attention of scholars in recent decades. Brand Tribalism has two main perspectives.

Business management and brand creation are all about creating a balance between two paradoxes. This phenomenon is also referred to as "dot" or connects theory (Farooq \& Raju, 2019a). Foundation of marketing is based on connections and relationships. These relationships start from customer to company, company to company at several levels (Kumar \& Shah, 2004). Companies are using the customer to customer relationships in the current era for the benefit of firms (Farooq et al., 2016). This customer to customer relationship has been referred to as 'brand tribe' or 'brand ambassadors' in the literature. A brand tribe is about a gathering of users of a brand. This research paper covers the two paradoxes in the brand tribe. The first paradox is postmodernism and the other one is the anthropological point of view.

Marketing has huge concentration of brand tribes. Brand tribalism has become a crucial notion, and long-term relationships can be developed between brands and consumers with the help of the vital role of brand tribes. Value is created for the consumers and businesses as well from the collective consumption known as consumer tribalism (Lee \& Kim, 2019) Brand tribalism is considered as a new strategy for building brand equity. It is weighty challenge for marketers because the creating process of brand tribalism is to build a network of individuals who have a passion for the same brand, have a connection, share emotions and opinions on the brand among the members in a group or tribe together (Kim et al., 2010; Lee et al., 2013; Lee \& Kim, 2019).

The efforts made for challenging task of creating brand tribes will be distracted if the measuring parameters of the brand tribe are unclear. Therefore, this research is focused on analyzing comparatively the two computing methods that are used by the postmodern school of thought and anthropological school of thought. Veloutsou and Moutinho (2009) has considered brand tribalism from a postmodern point of view and measured it with five variables comprising of the degree of fit with lifestyle, passion in life, reference group acceptance, social visibility, and collective memory. On the other hand, Taute and Sierra (2014) from an anthropological point of view recommended that defense of the tribe, social structure, segmentary lineage and sense of community are variables to define brand tribe (Taute \& Sierra, 2014; Lee \& Kim, 2019).

The first section talks of tribalism, the two main approaches in tribalism. The postmodern and anthropologist approaches. This section elaborators and compares the perspectives of different researchers on these two perspectives. The paper also contains the author findings in both explicit mentions which are given in the paper and explicitly finings which is drawn from connecting dots between different research papers using the deductive approach. The second section of the paper is about finding a scale for the measurement of both approaches. The author has adopted the questionnaire from earlier studies. The next section has the methodology and data collection steps. The section also contains the results and statistical validation of these results. The third section of the paper explains the findings and suggestions for practitioners and future researchers

\section{Literature Review}

Brand tribe represent group of people representing a brand and a perquisite towards loyalty. This importance of brand tribe led to measurement of brand tribalism (Cova \& Pace, 2006; Sierra et al., 2016). There are two ways to measure brand tribalism which are postmodern and anthropologist approach (Coelho et al., 2019). Postmodern approach talks about and Customer relationship marketing has highlighted and recognized the worth of brand tribe in the context of customer loyalty. Some authors have approached brand tribe from postmodern perspective but on the other hand, some have approached brand tribe from an anthropological point of view (Fournier \& Yao, 1997). While going for further research focusing on brand tribe, an unanswered puzzle comes into play that which approach is more appropriate for the measurement of brand tribe. Scholars who have followed the postmodern approach sorted/identified five constructs that are capable of measuring brand tribe. On the other hand, scholars following the anthropologist tactic have identified four variables for measuring brand tribe. In this research paper, the researchers have compared the two approaches in the automobile consumer market of Pakistan. The authors have sorted out the superior theoretical approach with the help of empirical evidence. Based on empirical evidence it has been concluded that brand tribe with respect to anthropological perspective are more capable of measuring the construct.

\subsection{Postmodern Scene of Brand Tribe}

According to definition of Maria \& Loureiro ( 2012); Schau, Muñiz, \& Arnould (2009) tribes are group of those 
people whose dedication is with specific brand. Likewise postmodern view of brand tribe is that it unites consumer in some social order for value (Cova \& Pace, 2006; Kozinets, 2006). Therefore, brands are consumed more for their social linking value rather than utilitarian or hedonic values (Kozinets, 2006; Nuttall et al., 2011) Tribal brands have similar values that progress around products. Creation of tribal brand undergoes thousands of social interactions amongst customers with different aspects of their favored brand (Veloutsou \& Moutinho, 2009). Brand tribes are different from conventional segmentation instead it demonstrates an example of continued devotees of a brand, having common interest and customs, lived and admired stories, perceived and observed experiences, and/or social and religious norms. Moreover, the people also share the same consciousness and affinity which means owning the feeling of moral responsibility for the people and brand (Veloutsou \& Moutinho, 2009). Similarly, the tribes are less devoted individually, comparatively more rewarding, more momentary, and more business-minded compared to other consumers (Goulding et al., 2013; Tan et al., 2013).

In the postmodern tribal model, six attributes of the tribes have been describing. The six attributes include the collective and holistic understanding of a person inside any community. The belonging of community gives him a feeling of security. The second aspect of the postmodern tribal model is the social life, the relationships between families, friends and acquaints. Religion also plays an important role in the postmodern tribal approach. Because of the religion, people create links and connections with each other. The fourth aspect of postmodern tribal system is tribal importance of collectivism rather than giving value to a single person. As per this approach, tribal people protect each other in difficult circumstances. The last aspect of postmodern approaches having the goal of a tribe. The goal of a tribe is preferred over individual preferences (Taute et al., 2017).

On scaling and measuring parameters (Veloutsou, 2015) constructed a structure of factors which persuade that relationship between a brand and its users have two dimensions. The dimension first aspect the contribution of both parties in building the relationship and the second aspect explains the relationship beyond transactional values which is the exchange of emotions. In the same direction, Veloutsou and Moutinho (2009) also develop a scale for measurement of tribalism which consists of items indicating the brand's fit with the consumer's lifestyle, passion in life, acceptance by relevant reference groups, social visibility, and collective memory; these dimensions are used and validated in the soft drink market (Veloutsou \& Moutinho, 2009) and mobile communications markets (Taute \& Sierra, 2014).

Collective memory has been defined as the brand knowledge the users which developed based on shared knowledge, in communities the knowledge is shared voluntarily with self-will instead of request from the brand or company. The information is also shared with the firm and in most cases between the members of the tribe (Veloutsou \& Moutinho 2009).

Brand tribe identification is defined as the perceived emotional attachment of a customer to other brand other users and supporters (Algesheimer et al., 2005) However, reference group acceptance of that user from other community members (Veloutsou \& Moutinho, 2009). These activities of acceptance and identification create the engagement between the users of a brand, which named as Brand tribe engagement. It is the degree of individual member motivation to participate in the brand group related activities (Taute \& Sierra, 2014). Social influences inculcate a pivotal role for impacting on decisions of users (Bagozzi, 2000). The consumers of a brand show their expression, identity by involving the brand tribes. Involvement with a tribe is an expression of self-identity; the consumer tribe shares moral values, opinions, consumption and preferences. Lifestyle also greatly influences consumer behavior and brand preferences. Consumers choose brands that are most suitable for their self-image. Accordingly, brands try to position in order to fit into consumers' lifestyle. Consumers seek ways in which consumers can use brands as an appropriate mean of self-showing (Cătălin \& Andreea, 2014; Sharma, 2013)

\subsection{Anthropological Scene of Brand Tribe}

Taute and Sierra (2014) gave four main pillars for developing a measurement scale for brand tribalism. The factors were; sense of community (which means the ability to maintain the harmony in tribe), the prevalence of a social network, segmentary lineage (which means combing different threads and segments. This also happens in social networking analysis, where different segments are brought on one page and connection between the segments build) and another key factor defense of the tribe (which is availing maximum by utilizing the strengths of the tribe. The strength of the tribe is built by collaborating with the more power tribes, competing with equal tribes and attaining power by attacking on feeble tribes).

Sahlins (1961) gave the theory of segmented lineage, which comprehensively describes the collective behavior of tribes. The author also gave the dimension approach pertaining to his view on tribal behavior. The first dimension of a tribe which is built on the usage of a brand is a common bond shared by different segments know 
as Lineage (Badrinarayanan et al., 2014; Sierra et al., 2016), which plays a crucial role in creating brand loyalty in several contexts. For example, preferences are passed to the children by parents for a particular brand which leads into the creation of a chain of loyalty (Taute \& Sierra, 2014). It is shared social and collective topographies which are the source of creation of lineage. Community members often feel strong associations among themselves which creates a strong bonding between brad users. As they use the same brand, because of similar their preferences, they build emotions with the people who have not met them before (Badrinarayanan et al., 2014). This relationship is based on liking a person or having the feeling of association with a tribe based on interest and passion; therefore it is not regulated by any public authority (Kabadayi \& Alan, 2012).

The second important approach in anthropological tribe settings is a social structure; for instance, the individuality that tribe members share. Tribal establishments are a level of social and cultural development; while members of prehistoric communities shared a sense of harmony, there was great social and economic subjugation among the respective community members (Sahlins, 1961). Similarly, in brand tribalism, social structure means a perceived sense of unity. Social structure is perilous for uniting members of a tribe who consumer a brand. The social structure not only represent the members' usage pattern but it also elaborates their characteristics such as the link of a grandfather with grandson through his son (Lee \& Kim, 2019).

Sense of community is the third pillar of the anthological approach of brand tribe. It means living in harmony. Moreover, this approach also emphasizes the co-existence with respect and acceptance of skills between the tribe members. As per literature, primitive communities had limitation of accepting social gathering which encounters fragmented political groups. The anthropological school of thought prefers the norms of society and the collective approach over fragmented segments (Sahlins, 1961). Moreover, in some contexts, the link is built on the mutual interest of living together without a well-known social structure; they would group together to achieve mutual objectives (Lee \& Kim, 2019). Therefore, a sense of community in brand tribe language is related to consumers' ability to cohabit tranquilly (Taute \& Sierra, 2014). The sense of living in harmony creates the feeling of "we" in the users, which creates a co-ownership attitude in parallel with co-existence. The users of the tribe except role of other members because of passion and similar interest rather than having a prominent regulated authority.

The fourth dimension is the defense of the tribe which is about fighting with both internal and external threats as a tribe. The dimension of defense of the tribe has multiple levels. The first level of defense is representing or to maintain the existence of the tribe. The second is availing the opportunities to strengthen the tribe and the third level is uniting against the threats (Lee \& Kim, 2019) In most the cases, the group get united and become more powerful when faced by any threat (Taute \& Sierra, 2014). This defensive conduct sometimes leads individual members of tribe (brand users) to feel a boosted sense of power in the pursuit of self-recognition/ increase in self-esteem. (De Hoog, 2013) The tribal behavior on the side gives identity to individual users of a brand, and the same aspect pushes the individuals to fight for the co-existence and co-ownership when faced by any threat (Lee \& Kim, 2019).

\subsection{Postmodernism Perspective vs. Anthropologist Perspective}

As the earlier section has explained both perspectives individually, here, the table 1 compares the explicit difference between modernism and anthropologist point of view about tribes. Both concepts represent the relationship management explicitly. However, there is one implicit message that firms can use in their marketing campaigns. Example of anthropologist approach is that in order to activate the group enthusiasm and get maximum from a tribe, the firms are supposed to create an opportunity or threat the users. The opportunity can be offering a limited benefit to the existing users. The concept was used by Netflix and HBO in their offers. When prices of Netflix were increased, the prices remained the same for earlier members for an extended period of 6 months (Farooq \& Raju, 2019a), which led to the creation of permanent of members in the tribe. Postmodern Approach: A firm applying the postmodern approach mostly believes in the categorization of the users. The categorization can be based on the recency, frequency and monetary value. The firms believing in this perspective mostly encourage the new users to buy their products and avail the joining offer. The concept of Bronze, silver and Gold employees is also based on the approach of post-Modern approach of relationship management (Farooq \& Raju, 2019b; Farooq et al., 2019). The key difference between camping's of these two perspectives is that the postmodern approach never finished the privileges of any category. The gold enjoys certain benefits because of being in the category while the anthropological approach is time-based which creates a sense of threat or losing with availing an opportunity. 
Table 1. Tribalism Approaches

\begin{tabular}{|c|c|c|c|}
\hline Definition/Perspective & Postmodernism Perspective & $\begin{array}{c}\text { Anthropologist } \\
\text { Perspective }\end{array}$ & $\begin{array}{c}\text { Description: Explicit or } \\
\text { Implicit Findings of Researcher }\end{array}$ \\
\hline $\begin{array}{l}\text { Key Authors or } \\
\text { Contributors }\end{array}$ & $\begin{array}{c}\text { Cleoparata Veloutsou and Luiz } \\
\text { Mouthinho }\end{array}$ & $\begin{array}{l}\text { Bernard Cova, } \\
\text { Veronique Cova }\end{array}$ & \\
\hline Derive from & $\begin{array}{c}\text { Relationship, Lifetime Concept of } \\
\text { Consumerism }\end{array}$ & Lineage Theory & $\begin{array}{l}\text { The first approach mainly } \\
\text { focuses on one-person own }\end{array}$ \\
\hline Key Constructs & $\begin{array}{l}\text { 1. Degree of fit with the lifestyle } \\
\text { 2. Passion in life } \\
\text { 3. Reference Group Acceptance } \\
\text { 4. Social Visibility } \\
\text { 5. Collective Memory }\end{array}$ & $\begin{array}{l}\text { 1. Segmentary Lineage } \\
\text { 2. Social Structure } \\
\text { 3. Defense of tribe } \\
\text { 4. Sense of Community }\end{array}$ & $\begin{array}{l}\text { preferences. Social hierarchy } \\
\text { and social visibility while the } \\
\text { anthropologist's view sees } \\
\text { things as community }\end{array}$ \\
\hline
\end{tabular}

\section{Source: Author Self Made Based on Literature}

The above comparison shows the more inclination of suggests Postmodernism Perspective towards the individuality while the Anthropologist Perspective has the dominant viewpoint of collective sociality. Anthropologist Perspective covers the social structure and community defense parameters which are mainly expressed as strong sides of Pakistani people; therefore, it is expected that people of Pakistan will favor the Anthropologist Perspective.

\section{Research Methodology}

For the validation of models, the author has selected the automobile industry as a metaphor to validate and compared models (Creswell \& Creswell, 2018). Automotive is a growing industry and a significant contributor to the GDP of Pakistan (Asghar, 2019). The reason behind selecting the automobile industry as a megaphone to validate the models is the love and association people with their vehicles. The researchers have selected and collected responses of automobiles which are in personal use of the people. As the personal use represent more affiliation and connection compared to the vehicles which are in business use.

\subsection{Sampling and User Details}

The researchers have collected the data from car users in Pakistan. As the population of the users exceeds 1 million; therefore, for sample selection, the Morgan (1970) table suggested volume of a sample of 384 should be used. To collect the desired number of samples, 900 car users were approached through two different questionnaires comprising 450 respondents for study 1 and 450 car users for study 2 . The subsequent sections explain both studies' demographic, descriptive and imperials statistics.

\subsection{Data Collection and Interpretation of Results}

\section{Study 1}

Brand tribalism concerning the postmodern view is measured by applying the scale explained by Veloutsou and Moutinho (2009). In the literature, five components are incorporated including 'reference group acceptance' is measured with five items, 'degree of fit with lifestyle' with five items, 'passion in life' with three items, 'social visibility of the brand' is measured with three items. All items were measured using seven-point Likert scales ranging from 1-strongly disagree to 7 -strongly agree.

\section{Study 2}

Brand tribalism from anthropological view is measured by applying the scale developed by Taute and Sierra (2014). Four elements which include 'lineage' measured with three items, 'social' is measured with the help of three items, and 'defense of tribe' is measured with five items, whereas 'sense of community' is measured with five items. Scale remained the same as 7-point Likert.

\subsection{Population and Sample Profile}

Geographically the population of the whole country is divided in four major provinces i.e. Khyber Pakhtunkhwa (KPK), Sindh, Punjab and Baluchistan, the capital city 'Islamabad' and states of Azad Jammu \& Kashmir (AJK) and Gilgit-Baltistan (GB), as per Pakistan Bureau of Statistics (PBS) total population of Pakistan according to 2017 census was 212742631 (PBS, 2017). For this study sample of 450 was aimed to be extracted as per population percentage ratio. 
Table 2. The Geographic distribution of Pakistan's population.

\begin{tabular}{cccc}
\hline Clusters (state/province) & Population & Percentage & Ratio to Sample of 450 \\
\hline Khyber Pakhtunkhwa (KPK) & $35,525,047$ & 16.70 & 75 \\
Sindh & $47,886,051$ & 22.51 & 101 \\
Punjab & $110,012,442$ & 51.71 & 233 \\
Baluchistan & $12,344,408$ & 5.80 & 26 \\
Capital-Islamabad & $2,006,572$ & 0.94 & 4 \\
AJK+GB & $4,968,111$ & 2.34 & 11 \\
Total & $\mathbf{2 1 2 , 7 4 2 , 6 3 1}$ & & $\mathbf{4 5 0}$ \\
\hline
\end{tabular}

Data collected for study 1 is composed of 404 car user across Pakistan, whereas 392 respondents provided meaningful data for measurement analysis.

Table 3. Location of users, collected data countrywide

\begin{tabular}{ccccc}
\hline \multirow{2}{*}{ Clusters (state/province) } & \multicolumn{2}{c}{ Study 1- Sample } & \multicolumn{2}{c}{ Study 2-Sample } \\
\cline { 2 - 5 } & Frequency & Percent & Frequency & Percent \\
\hline Capital-Islamabad & 4 & 1.0 & 4 & 1.0 \\
AJK+GB & 10 & 2.5 & 7 & 1.8 \\
Sindh & 99 & 24.5 & 94 & 24.0 \\
Baluchistan & 17 & 4.2 & 193 & 6.1 \\
Punjab & 199 & 49.3 & 70 & 17.2 \\
Khyber Pakhtunkhwa (KPK) & 75 & 18.6 & 392 & 100.0 \\
Total & 404 & 100.0 & &
\end{tabular}

\subsection{Reliability and Validity}

Study 1 Reliability and Validity Statistics:

Composite reliability (CR) was estimated to examine the internal consistency of each sub-variable of the main factor. Studies recommend the generally accepted threshold level is 0.7 (Chen 1998; Fornell and Larcker 1981). CR value was found 0.83 which is significantly above 0.7 .

According to Fornell and Larcker (1981), to clear convergent validity test, the factor loading of each measure should exceed 0.7, and average variance extracted (AVE) values should exceed 0.5. All the factors were ranged from 0.59 to 0.82 , three variables were found below the cut point of .7 and the AVE was 0.49 just below the benchmark of 0.5 , representing poor the values to meet the suggested criteria.

A series of second-order confirmatory factor analyses were conducted to investigate whether band tribe variables captured distinctive constructs using Amos 2. The results shown in table for brand tribe w.r.t postmodern perspective five-factor model fit the data most well as compared to others but was unable to achieve the least expected values of the model fit: $\chi^{2}=533.4, \mathrm{df}=99, \mathrm{CFI}=.82, \mathrm{GFI}=.85, \mathrm{TLI}=.78, \mathrm{RMR}=.189$, RMSEA $=.104$ (Duanxu, 2016). The other models presented worst results as we approached to one-factor model which fits most poorly: $\chi^{2}=108.9, \mathrm{df}=104, \mathrm{CFI}=.59, \mathrm{GFI}=.70, \mathrm{TLI}=.53, \mathrm{RMR}=.229, \mathrm{RMSEA}=.153$. The $\chi^{2}$ difference between these two models was found significant $\left(\Delta \chi^{2}=548.5, \mathrm{p}<.01\right)$, providing evidence of different factors but useless because of model fitness as per defined thresholds (Hair et al., 2014).

Table 4. Reliability and Convergent Validity Statistics

\begin{tabular}{ll}
\hline Brand Tribe Postmodern approach $(\mathrm{CR}=0.83, \mathrm{AVE}=0.49)$ & Factor Loading $(\lambda)$ \\
\hline Degree of fit with lifestyle & 0.82 \\
Passion in life & 0.77 \\
Reference Group Acceptance & 0.59 \\
Social Visibility & 0.65 \\
Collective Memory & 0.68 \\
\hline
\end{tabular}


Table 5. Measurement model comparisons

\begin{tabular}{ccccccccc}
\hline Measurement model & $\chi^{2}$ & $\mathrm{df}$ & $\Delta \chi^{2}$ & CFI & GFI & TLI & RMR & RMSEA \\
\hline 1. Five-Construct measurement model & 533.4 & 99 & -- & 0.82 & 0.85 & 0.78 & 0.189 & 0.104 \\
2. Four-Construct measurement model & 524.8 & 100 & -8.6 & 0.82 & 0.84 & 0.79 & 0.170 & 0.103 \\
3. Four-Construct measurement model & 651.0 & 100 & 117.6 & 0.77 & 0.81 & 0.72 & 0.192 & 0.117 \\
4. Three-Construct measurement model & 852.9 & 102 & 319.5 & 0.69 & 0.68 & 0.63 & 0.226 & 0.135 \\
5. Two-Construct measurement model & 909.5 & 103 & 376.1 & 0.64 & 0.73 & 0.59 & 0.252 & 0.144 \\
6. One-Construct measurement model & 1081.9 & 104 & 548.5 & 0.59 & 0.70 & 0.53 & 0.229 & 0.153
\end{tabular}

Note: $n=404$ Model 2 merges degree of fit with lifestyle and passion in life, model 3 merges collective memory and social visibility, model 4 merges collective memory in passion in life and social visibility in ref group, in model 5 collective memory and passion in life is merged with degree of fit with lifestyle and social visibility with ref group, in model 6 all variables merged as one construct. $\Delta \chi^{2}$ is with respect to Model 1

\section{Study 2 Reliability and Validity Statistics}

Composite reliability (CR) was estimated to examine the internal consistency of each sub-variable of the main factor. Studies recommend the generally accepted threshold level is 0.7 (Chen, 1998; Fornell \& Larcker, 1981). CR value was found 0.94 which is significantly above 0.7 as per thresholds (Hair et al., 2014).

All the factors were ranged from 0.85 to 0.94 , and the AVE was 0.82 exceeded the benchmark of 0.5 , indicating the values met the suggested criteria of convergent validity.

A series of second-order confirmatory factor analyses were conducted to investigate whether band tribe variables captured distinctive constructs using Amos 21. To evaluate the discrimination of variables Duanxu (2016) method is adopted. The result shown in Table for brand tribe w.r.t anthropology four-factor model fit the data most sound: $\chi^{2}=328.5, \mathrm{df}=98, \mathrm{CFI}=.93, \mathrm{GFI}=.91$, TLI $=.92, \mathrm{RMR}=.108, \mathrm{RMSEA}=.079$ as compared to one-factor model which fits very poorly: $\chi^{2}=611.9, \mathrm{df}=104, \mathrm{CFI}=.86, \mathrm{GFI}=.83$, TLI $=.84, \mathrm{RMR}=.132$, RMSEA $=.112$. The $\chi^{2}$ difference between these two models was found significant $\left(\Delta \chi^{2}=283.7, p<.01\right)$, providing evidence of different factors. Furthermore, to test either these variables are distinct various combinations of factors with the various grouping of items were tried. The ultimate result showed that the four-factor model was best among all other alternatives including three-factor models, two factors and one-factor model. These outcomes as shown in the Table 7, supported the discriminate validity.

Table 6. Reliability and Convergent Validity Statistics

\begin{tabular}{ll}
\hline Brand Tribe Anthropological approach $(\mathrm{CR}=0.94, \mathrm{AVE}=0.82)$ & Factor Loading $(\lambda)$ \\
\hline Social Structure & 0.91 \\
Defense of tribe & 0.92 \\
Sense of Community & 0.94 \\
Segment Lineage & 0.85 \\
\hline
\end{tabular}

Table 7. Measurement model comparisons

\begin{tabular}{ccccccccc}
\hline Measurement model & $\chi^{2}$ & df & $\Delta \chi^{2}$ & CFI & GFI & TLI & RMR & RMSEA \\
\hline 1. Four-Construct measurement model & 328.2 & 98 & -- & 0.93 & 0.91 & 0.92 & 0.108 & 0.079 \\
2. Three-Construct measurement model & 387.4 & 101 & 59.2 & 0.92 & 0.89 & 0.91 & 0.109 & 0.085 \\
3. Three-Construct measurement model & 408.4 & 101 & 80.2 & 0.91 & 0.88 & 0.9 & 0.118 & 0.088 \\
4. Three-Construct measurement model & 510.8 & 101 & 182.6 & 0.89 & 0.85 & 0.87 & 0.119 & 0.102 \\
5.Two- Construct measurement model & 532.8 & 103 & 204.6 & 0.88 & 0.85 & 0.86 & 0.121 & 0.103 \\
6. One-Construct measurement model & 611.9 & 104 & 283.7 & 0.86 & 0.83 & 0.84 & 0.132 & 0.112 \\
\hline
\end{tabular}

Note: $n=392$. Model 2 merges Segmentary linage and social structure, model 3 merges social structure and defense of tribe, model 4 merges sense of community and defense of tribe, in model 5 sense of community is merged with defense of tribe and social structure with Segmentary lineage, in model 6 all variables merged as one construct. $\Delta \chi 2$ is with respect to Model 1 


\section{Conclusion and Discussion}

Based on the results of study- 1 and study-2 shown in the Tables 5 and 7, the researcher has concluded that the four-factor model of study-2 is a good fit in the context of car users industry of Pakistan. The paper concludes that the anthropologist approach of measuring tribe behavior is fit in the context of the Pakistani market. Furthermore, in elaboration, the study concludes segment lineage, social structure, defense of tribe and sense of community are more important for tribe behavior than the degree of fit with lifestyle, passion in life, reference group acceptance, social visibility and collective memory.

Besides validating the scale and approach of anthropologist, the current research results are aligned with Hofstede cultural dimensions about Pakistan (Pakistan - Hofstede Insights, 2020).

In Hofstede cultural dimensions, people of Pakistan have very less individualism. Therefore, they have rejected the tribe model which is based on individualism. The research results are also aligned with dimension uncertainty avoidance. As in anthropologist approach, the users are asked for activities based on threat or opportunity and there are clear rewarded linked with it with least uncertainty; therefore, the users prefer the community sense. Moreover, the key parameters of anthropologist such as segment lineage, social structure, and defense of tribe and sense of community are creating a sense of security (uncertainty avoidance) and collectivism.

\section{Recommendations for Future Researchers}

As evident from earlier studies, that people of Pakistan have a collective mindset and uncertainty avoiding attitude; therefore they have responded in a better way for segment lineage, social structure, defense of tribe and sense of community. The current study recommends the practitioners to favor the collective approach in marketing and loyalty campaign design over individual approach. As this paper has only covered the automobile industry, therefore, the author recommends further research, in the context of other industries such as food products, cellular services to authenticate the model fitness. Besides focusing on other industries, future research can also view the moderating role of income, education, age and gender. The impact of impact can also impact in luxury products or inexpensive goods such as automobiles. Therefore, the future researchers implementing this model are also recommended to take income as impacting variable.

\section{References}

A. Taute, H., \& Sierra, J. (2014). Brand tribalism: An anthropological perspective. Journal of Product \& Brand Management, 23(1), 2-15. https://doi.org/10.1108/JPBM-06-2013-0340

Arooj Asghar. (2019). Overview of auto sector of Pakistan. Pakistan \& Gulf Economist.

Arvidsson, A. (2005). Brands. Journal of Consumer Culture, 5(2), 235-258. https://doi.org/10.1177/1469540505053093

Ataman, M. B., Mela, C. F., \& Van Heerde, H. J. (2008). Building brands. Marketing Science. https://doi.org/10.1287/mksc. 1080.0358

Badrinarayanan, V. A., Sierra, J. J., \& Taute, H. A. (2014). Determinants and Outcomes of Online Brand Tribalism: Exploring Communities of Massively Multiplayer Online Role Playing Games ( MMORPGs ). Psychology and Marketing, 31(10), 853-870. https://doi.org/10.1002/mar

Bauer, H. H., Stokburger-Sauer, N. E., \& Exler, S. (2008). Brand Image and Fan Loyalty in Professional Team Sport: A Refined Model and Empirical Assessment. Journal of Sport Management, 22(2), 205-226. http://10.0.4.99/jsm.22.2.205

Cătălin, M. C., \& Andreea, P. (2014). Brands as a Mean of Consumer Self-expression and Desired Personal Lifestyle. Procedia - Social and Behavioral Sciences, 109, 103-107. https://doi.org/10.1016/j.sbspro.2013.12.427

Chapman, C. (2020). Commentary: Mind Your Text in Marketing Practice. In Journal of Marketing (Vol. 84, Issue 1). https://doi.org/10.1177/0022242919886882

Coelho, A., Bairrada, C., \& Peres, F. (2019). Brand communities' relational outcomes, through brand love. Journal of Product and Brand Management, 28(2), 154-165. https://doi.org/10.1108/JPBM-09-2017-1593

Cova, B., \& Pace, S. (2006). Brand community of convenience products: New forms of customer empowerment - the case "my Nutella The Community." European Journal of Marketing, 40(9/10), 1087-1105. https://doi.org/10.1108/03090560610681023

Creswell, J. W., \& Creswell, J. D. (2018). Research Design: Qualitative, Quantitative, and Mixed Methods 
Approaches. In Sage (Vol. 67, Issue 6).

de Kock, J., Roeland, J., \& Vos, P. (2011). Beyond individualisation: Neo-evangelical lessons for religious socialisation. Journal of Beliefs \& Values, 32(3), 329-342. https://doi.org/10.1080/13617672.2011.627699

Donnelly, M., Holden, M. T., \& Lynch, P. (2009). Building Customer Loyalty: A Customer Experience Based Approach in a Tourism Context. June, 1-303.

Duanxu, W. (2016). LMX and employee voice: A moderated mediation model of psychological empowerment and role clarity. Personnel Review, 45(3), 605-615. https://doi.org/10.1108/PR-11-2014-0255

Escalas, J. E., \& Bettman, J. R. (2005). Consumer Culture Theory (CCT): Twenty Years of Research. Journal of Consumer Research, 32(3), 378-389. https://doi.org/10.1086/678302

Farooq, M., Janjua, S. Y., \& Khurshid, M. A. (2016). Customer-based brand equity and firms' performance in the telecom industry. International Journal of Services and Operations Management, 25(3), 334. https://doi.org/10.1504/IJSOM.2016.079516

Farooq, M., Khalil-Ur-Rehman, F., Abdurrahaman, D. T., Younas, W., Sajjad, S., \& Zreen, A. (2019). Service Quality Analysis Of Private Universities Libraries In Malaysia In The Era Of Transformative Marketing. International Journal for Quality Research, 13(2), 269-284. https://doi.org/10.24874/IJQR13.02-02

Farooq, M., \& Raju, V. (2019). Impact of Over-the-Top (OTT) Services on the Telecom Companies in the Era of Transformative Marketing. Global Journal of Flexible Systems Management, 20(2), 177-188. https://doi.org/10.1007/s40171-019-00209-6

Fournier, S., \& Yao, J. L. (1997). Reviving brand loyalty: A reconceptualization within the framework of consumer-brand relationships. International Journal of Research in Marketing, 14(5), 451-472. https://doi.org/10.1016/S0167-8116(97)00021-9

Goulding, C., Shankar, A., \& Canniford, R. (2013). Learning to be tribal: Facilitating the formation of consumer tribes. European Journal of Marketing, 47(5/6), 813-832. https://doi.org/10.1108/03090561311306886

Hair, J., Hult, G. T. M., Ringle, C., \& Sarstedt, M. (2014). A Primer on Partial Least Squares Structural Equation Modeling (PLS-SEM).

Irshad, M., \& Farooq, M. (2015). Effect of Brand Tribalism on Customer Loyalty. Jurnal GMP Review of Marketing. https://www.researchgate.net/publication/285322441

Kabadayi, E. T., \& Alan, A. K. (2012). Brand Trust and Brand Affect: Their Strategic Importance on Brand Loyalty. Journal of Global Strategic Management, 6(1), 80-88.

Kim, Y. H., Goh, B. K., \& Yuan, J. (Jessica). (2010). Development of a Multi-Dimensional Scale for Measuring Food Tourist Motivations. Journal of Quality Assurance in Hospitality \& Tourism, 11(1), 56-71. https://doi.org/10.1080/15280080903520568

Kotler, P., \& Armstrong, G. (2010). Principles of Marketing. World Wide Web Internet And Web Information Systems, 785. https://doi.org/10.2307/1250103

Kozinets, R. V. (2006). Click to connect: Netnography and tribal advertising. Journal of Advertising Research, 46(3), 279-288. https://doi.org/10.2501/S0021849906060338

Kumar, V., \& Shah, D. (2004). Building and sustaining profitable customer loyalty for the 21 st century. Journal of Retailing, 80(4), 317-330. https://doi.org/10.1016/j.jretai.2004.10.007

Lee, T. H., Jan, F., \& Yang, C. (2013). Environmentally responsible behavior of nature-based tourists : A review. 2(1), $100-115$.

Lee, Y., \& Kim, I. (2019). A value co-creation model in brand tribes: The effect of luxury cruise consumers' power perception. Service Business, 13(1), 129-152. https://doi.org/10.1007/s11628-018-0373-x

Maria, S., \& Loureiro, C. (2012). Consumer- Consumer - brand relationship: Relationship: Foundation and state- state - of- of - art. 2004, 1-20.

Nuttall, P., Arnold, S., Carless, L., Crockford, L., Finnamore, K., Frazier, R., \& Hill, A. (2011). Understanding music consumption through a tribal lens. Journal of Retailing and Consumer Services, 18(2), 152-159. https://doi.org/10.1016/j.jretconser.2010.12.007

Pakistan - Hofstede Insights. (2020). Hofstede Insights.

PBS. (2017). Population Census Report 2017. 
Ramaiyah \& Ahmad, H. A., Aydin, S., Özer, G., Haryanto, J. O., Moutinho, L., Aldas-Manzano, J., ... Brea, J. A. F. (2010). Service quality dimensions: An examination of Grönroos's service quality model. European Journal of Marketing, 8(4), 488-491. https://doi.org/10.1017/CBO9781107415324.004

Raza, M., Frooghi, R., Rani, D. S. H. binti, \& Qureshi, M. A. (2018). Impact of Brand Equity Drivers on Purchase Intention: A Moderating Effect of Entrepreneurial Marketing. South Asian Journal of Management Sciences, 12(1), 69-92. https://doi.org/10.1136/bmj.38623.768588.47

Reich, T., \& Maglio, S. J. (2020). Featuring Mistakes: The Persuasive Impact of Purchase Mistakes in Online Reviews. Journal of Marketing, 84(1). https://doi.org/10.1177/0022242919882428

Reimer, J. K. K., \& Walter, P. (2013). How do you know it when you see it? Community-based ecotourism in the Cardamom Mountains of southwestern Cambodia. Tourism Management, 34, 122-132. https://doi.org/10.1016/j.tourman.2012.04.002

Sahlins, M. D. (1961). The Segmentary Lineage: An Organization of Predatory Expansion. American Anthropologist, 63(2), 322-345.

Schau, H. J., Muñiz, A. M., \& Arnould, E. J. (2009). How Brand Community Practices Create Value. Journal of Marketing, 73(5), 30-51. https://doi.org/10.1509/jmkg.73.5.30

Sharma, H. J. (2013). Effect of Gender and Family Income on Brand Tribalism with Special Emphasis on Mobile Phone Users in Ahmedabad. Journal of Chemical Information and Modeling, 53(9), 1689-1699. https://doi.org/10.1017/CBO9781107415324.004

Sierra, J. J., Badrinarayanan, V. A., \& Taute, H. A. (2016). Explaining behavior in brand communities: A sequential model of attachment, tribalism, and self-esteem. Computers in Human Behavior, 55, 626-632. https://doi.org/10.1016/j.chb.2015.10.009

Szõcs, A. (2014). Consumer-Based Brand Equity: A literature review. Journal of Economics \& Business Research, $20(1)$ 93-120. http://search.ebscohost.com/login.aspx?direct=true \&db=bth\&AN=98654375\&site=ehost-live

Tan, S.-K., Kung, S.-F., \& Luh, D.-B. (2013). a Model of "Creative Experience" in Creative Tourism. Annals of Tourism Research, 41, 153-174. https://doi.org/10.1016/j.annals.2012.12.002

Taute, H. A., Sierra, J. J., Carter, L. L., \& Maher, A. A. (2017). A sequential process of brand tribalism, brand pride and brand attitude to explain purchase intention: A cross-continent replication study. Journal of Product \& Brand Management, 26(3), 239-250. https://doi.org/10.1108/JPBM-08-2016-1289

Tsai, S. (2005). Utility, cultural symbolism and emotion: A comprehensive model of brand purchase value, 22, 277-291. https://doi.org/10.1016/j.jiresmar.2004.11.002

Veloutsou, C. (2015). Brand evaluation, satisfaction and trust as predictors of brand loyalty: The mediator-moderator effect of brand relationships. Journal of Consumer Marketing, 32(6), 405-421. https://doi.org/10.1108/JCM-02-2014-0878

Veloutsou, C., \& Moutinho, L. (2009). Brand relationships through brand reputation and brand tribalism. Journal of Business Research, 62(3), 314-322.

Zeithaml, V. A., Jaworski, B. J., Kohli, A. K., Tuli, K. R., Ulaga, W., \& Zaltman, G. (2020). A Theories-in-Use Approach to Building Marketing Theory. Journal of Marketing, 84(1). https://doi.org/10.1177/0022242919888477

\section{Copyrights}

Copyright for this article is retained by the author(s), with first publication rights granted to the journal.

This is an open-access article distributed under the terms and conditions of the Creative Commons Attribution license (http://creativecommons.org/licenses/by/4.0/). 